\author{
Ines Crvenkovska Risteska, (North Macedonia) \\ Institute of Ethnology and Anthropology \\ Faculty of Natural Sciences and Mathematics \\ Ss. Cyril and Methodius University - Skopje \\ e-mail: ines.crvenkovska@pmf.ukim.mk
}

\title{
THE DEPICTION OF ROMA IN THE MACEDONIAN ETHNOLOGICAL AND ANTHROPOLOGICAL LITERATURE
}

\begin{abstract}
A relatively small number of ethnological papers deal with the Roma in the Balkans, including Macedonia. In this paper, the idea is to present how the scientific interest in Roma issues increased than how the image of the Roma was conceived in Yugoslavian literature. This image was then transferred to the Macedonian ethnological, anthropological literature. The analysis has used ethnographic papers and proceedings dedicated to the Roma in the period of the Socialist Federal Republic of Yugoslavia (SFR Yugoslavia) in the '70s, ' 80 s, and '90s, and papers about the Roma, published in the Republic of Macedonia since its independence in 1991.

In some of these papers, one can notice how the ethnologists and anthropologists build their image of the Roma in several directions. First, at the very beginning in the Yugoslavian, and then in Macedonian ethnology and anthropology, which copied the same model, the importance of researching the Roma as an important Yugoslavian nationality is stressed. On the other hand, an image of the Roma as the Yugoslavian 'otherness' is being built, followed by recommendations that ethnologists from the Roma community should research it. As a result of the efforts to employ Roma ethnologists at a Yugoslavian level, most of the Macedonian researchers who started dealing with the Roma community are Roma-educated in Yugoslavia.

After the dissolution of SFR Yugoslavia and the concept of a Yugoslavian nationality, made up of brotherly peoples and minorities, the idea of the Roma 'otherness', through the concept of Roma national tradition, lives on within the national programs of the Balkans. Moreover, the concept of Roma 'otherness', stemming from Yugoslavian ethnology, endures in Roma's researchers works in modern Macedonian ethnological literature.
\end{abstract}

Keywords: The Roma, ethnology, anthropology, ethnological - anthropological literature, Balkan 'otherness.' 
“...Belgrade, as well as our other cities (especially Skopje), have mushroomed in size in the last few decades. In light of the ethnological analyses, the demographic data also demonstrate that the Roma have contributed to all of this. Even more than that. The Roma, especially their women, with their active managerial role outside of the house, bestow our cities an idiosyncratic, and according to some, even an oriental flavor" (Knezevic 1982: 280).

\section{Introduction}

The number of ethnological papers that deal with topics related to the Roma communities in SFR Yugoslavia is relatively low. There are even fewer papers dedicated to the Roma communities in the Republic of Macedonia since its independence. In this paper, we will try to discern the types of discussions led by the ethnologists and anthropologists in their papers on the Roma, as well as the theoretical frameworks used to build specific images of the Roma in SFR Yugoslavia, which, more or less, survived in their works even in the period after the dissolution of SFR Yugoslavia, in the independent Republic of Macedonia. To illustrate these images, this paper will use interpretations from ethnographic articles published in proceedings dedicated to the Roma in the '70s, ' 80 s, and '90s and from research monographs and papers published since Macedonian independence. At the beginning in Yugoslavian ethnological literature, and then in its Macedonian counterpart, which copied the same model of ethnographic approach and interpretation for the Roma, an Orientalized image of the Roma and the Romni (female Roma, translator's note) is being built. At the same time, a picture is being constructed of the Roma as the Yugoslavian 'otherness'. While discussing the Roma, S. Knezevic, in a 1982 paper, already quoted, specifically the managerial role of the Romni outside the house, stresses the fact that they were present in the cities and concludes that this fact bestows cities an idiosyncratic, oriental flavor.

This paper represents a brief critical review of how such an approach in the ethnological and anthropological research for the Roma was built until now. Of course, I do not intend for this paper to be taken as a brief "morality fairytale" (Todorova 2001: $\mathrm{x})$, nor as an appendix or rectification of certain inconsistencies in the research done in previous periods. On the contrary, the sole purpose of this paper is to point to the need for constant revision of the approach towards the sociocultural communities, including that of the Roma, to preserve the relativist attitude in the Roma-related topics, treating them as equally serious as the other topics in ethnology and anthropology.

While creating this brief critical review, we will try to get acquainted with the images, or, as they are also called, pictures in our heads (Rot 2000) and their use in setting certain "social boundaries," as Styke calls them, created by ethnologists in the papers about the Roma. Still, we will also examine the reasons why they remained in the ethnographic writings until today. Generally, the main driving force for nurturing such views is their creation, based on generalizations founded on reductionism (Todorova 2001: 3). These generalizations, on behalf of "scientific facts," are complemented 
by new, reduced conceptions used to support and maintain stereotypes for the Roma communities, as a "definition for a sociocultural whole," which is constantly reiterated throughout literature.

\section{Yugoslavian ethnology for the Roma: theoretical aspects in the socialist period}

Starting from the " 70 s and then in the ' 80 s and ' 90 s, the Yugoslavian ethnologists intensified their writing about the Yugoslavian Roma. They wrote papers that spurred the ethnologists to become more interested in carrying research on the Roma communities. Naturally, their works were focused on their colleagues, but they were exceedingly important to affect the Roma communities. This was so because they worked in line with the then-dominant state strategy, which also influenced the senior scientific circles, to work in the spirit of the Yugoslavian nation, where all peoples and minorities had equal rights and significance, and this included the discussions on the Roma as a distinct minority. Therefore, when writing about the Roma communities in a particular part of SFR Yugoslavia, the ethnologists usually correlated them with the other Roma communities throughout Yugoslavia, treating them as a single ethnic/minority category.

In this sense, the ethnologists actively wrote to ascertain the theoreticalmethodological orientation of Yugoslavian ethnology (Bajraktarevic 1982:155) to construct unitary Yugoslavian ethnology. Thus it was proposed that the ethnologists would be required, in terms of the methodology and methods used, "to go for the ideology of the working class, expressed through Marxism, for a theory based on a dialect - materialist foundation" (Bajraktarevic 1982:159). In that way, the work of the ethnologists in socialism was opposed to the older ethnologists' theory and methodology from the period between the two world wars, when "anthropogeography is used to perpetuate the liberalist bourgeoisie ideology..." (Bajraktarevic 1982: 160). In this sense, M. Bajraktarevic finds the research and processing of the material for the ethnological atlas of Yugoslavia of crucial importance. Then a particular ethnologic theory and methodology for the ethnology in Yugoslavia were developed (Bajraktarevic 1982: 160). Bajraktarevic put special emphasis on the development of the ethnology of the peoples and minorities in Yugoslavia and proposed the direction that the work of the Yugoslavian ethnologists should take, who "by no means, especially as scientific workers, may circumvent the minorities" (Bajraktarevic 1982: 156). Thus, the directions for the development of Yugoslavian ethnology were set for the issue of the Roma as a minority in SFR Yugoslavia.

In addition, the idea of talking about the Roma in the ethnological and anthropological literature can be found as early as the 80's in the papers by Yugoslavian and Macedonian ethnologists in SFR Yugoslavia. In the research of the Bitola Roma communities, and regards to establishing the term Roma (Rom, Romni), ethnologist Konstantinov wrote that the Bitola Roma have been reluctant to accept it in recent years. He also mentioned that younger generations generally accepted this term (Konstantinov 1982: 252), and it is all-encompassing for the various communities identified by language and occupation. In the group of Roma communities in the city of Bitola, Konstantinov includes the communities on account of how they call themselves. Still, he also adds 
specific additional qualifications that are imaginary traditions for the Roma communities. In essence, they are unprovable and anthropologically irrelevant: Gjupci (Egjupci), Turci Gjupci, Risjan Gjupci - K'pti - which Konstantinov believes is a term that disappears and is replaced by 'Macedonian,' then Chergari and Kurtofi, and for the first three groups he writes that "they are, by lineage, at a level that is superior to the two last ones; however, they underestimate themselves, in line with the subconsciously entrenched cast traditions and beliefs from India" (Konstantinov 1982: 252). In that way, Konstantinov, supported by the other ethnological papers in the proceedings of a conference attended by key Yugoslavian ethnologists, suggests adopting a research approach that would not distinguish between the Roma based on their place of residence (city or village). This approach Konstantinov believes to be "natural" (Konstantinov 1982: 247), primarily, as he notes, in the Bitola Roma people, since they represent a unique ethnic community, interwoven internally by the diverse values of its spiritual and material culture. Such an approach in ethnological research is preserved even a decade later among ethnologists who try to continue the discussion on Yugoslavian Roma. Gjurgiica Petrovic uses such an approach in 1992, who is pleased that there have been at least 508 bibliographic units dedicated to the Roma until then. It discusses the numerous monumental works that describe Yugoslavian Roma, which "largely encapsulate the ethnological interest for this self-aware and authentic ethnic community" (Petrovic 1992: 61). With such an ethnological view of Yugoslavian researchers, the Roma are considered a homogenous community. Their "natural" cohesiveness in a single ethnic community can be used as a foundation for building the concept of a Roma minority within the Yugoslavian nationstate.

This points to the fact that the Roma are discussed much more clearly in the ethnological and anthropological literature of the ' 90 s, at the conference on the Roma. Then Sait Balic, the president of the International Organization of the Roma, underlined a specific feature of the Roma, namely that they have "passed all Scylla and Charybdis," who have endured all the injustice and humiliation, who, on their long journey from India to the rest of the world, did not cause inequity or harm to anybody, (and) who know how to appreciate all human gestures and acts that are intertwined with the idea of humanity" (Balic 1992: 3).

In terms of the moment when one can talk about more focused monitoring of the Roma culture in Yugoslavia, in the opening address of the scientific conference The Development of the Roma in Yugoslavia - Issues and Tendencies in 1992, academic Milosh Macura underlines the importance of the scientific conference held in 1976 by the Serbian Academy of Sciences and Arts entitled The Life and Customs of the Roma in our country when it was proposed that the Academy, in the future, should pay greater attention to the Roma studies. To that end, it should establish a competent body. Thus, the presidentship of the Serbian Academy of Sciences and Arts agreed in 1977 to establish a particular working group for studying the Roma within the boundaries of the ethnographic board. Unfortunately, because of a shortage of staff and funds for scientific research, the group was disbanded in 1978. However, the idea of studying the Roma life and customs was not abandoned. On the contrary, it was believed that in Sarajevo and in Skopje, where, according to the opinion of the specialists, the study of the Roma language and the other expressions of the spiritual life of the Roma had made great strides, "the 
idea of establishing an inter-academic board will be launched, which would also meet the requirements of the Serbian Academy of Sciences and Arts for working on this important topic" (Macura 1992: 1).

The 90's mark an abrupt change in the relationship between ethnologists and research topics covering the Roma, since it becomes popular to write about the Roma, but also to write motivational texts that stress the importance of researching Romarelated issues, in which the Roma are especially encouraged to tackle ethnological topics. This supports research "from the inside out," which is the case in all SFR Yugoslavia communities in that period. In the case of the Roma, the study in this period features a research discourse towards the Roma as if they were a marginalized group, with ideas to monitor the country's social policy towards them and already carry out research about the prejudices and stereotypes related to the Roma population. In this sense, on one occasion, Petrovic wrote that "all purpose-written papers on the Roma in Yugoslavia... represent a firm foundation for expanding and continuing the work that the Roma researchers have already begun. Since the ' 70 s, the interest of scientists... for this ethnic community, which can still be found on the margins of society, grew"(Petrovic 1992: 62). Thus, she places this development in the context of the importance of the Roma raising their voice to change their status and position in society, in general... as well as getting additional researchers from a broader spectrum of scientific disciplines involved in the study of the past and present of the Yugoslavian Roma" (Petrovic 1992: 62). This positive energy in the period will increase the number of Roma ethnologists in Yugoslavian ethnology that study the Roma communities from the '70s onwards, which strengthens the insider approach in the research of the Roma culture that was considered to be the most reliable. Of course, this contributed to more thorough and more substantiated qualitative research, and the position of the Roma members of research institutions and circles was also bolstered. In this sense, the Roma researchers who had the opportunity to be in senior positions in the institutions that carry out scientific research in the SFR Yugoslavia, such as the presidency of the Serbian Academy of Sciences and Arts, managed to organize three scientific conferences dedicated to the Roma in Yugoslavia covering the period until the '90s. At these events, they are deeply grateful when addressing "the friends of the Roma people, who have suffered for centuries and who have been oppressed in modern times, and in whose destiny all the injustices and evils of the modern world are inscribed" (Kanazira 1993: 3).

\section{Establishing the Roma "otherness" in Yugoslavian ethnology}

In the 1982 paper by Srebrica Knezevic entitled The Romni and Their Sense of Adaptation in Line With the Changes in Economy, in which she expounds on the theoretical hypotheses in her analysis which is based on 50 years, the author focuses on bringing light to the range of mutually independent issues, starting from the intensity of the infiltration of the perpetual nomads in the setting of a city, by the fact that they get tied down to a permanent territory and by acquiring habits typical of a sedentary life 
through a type of adaptation to the economic field (Knezevic 1982: 280). This qualification and treatment of the Roma, as "perpetual nomads," can be found among other ethnologist authors in this period, but also among Macedonian authors in the 90's, which expands the image of the Bitola Roma as unusually mobile, since even the perpetual movement is a feature of their restless, wanderer blood (Konstantinov 1982: 267).

Knezevic, based on the material she possessed in the research we mentioned above, focuses her draft hypothesis on the effort to observe the influence of the city environment on the Roma (when the Roma accept it and adjust to the city environment) more than in the case of the other ethnic communities, and much more on the change and adaptation of the habits and customs of the city environment towards the traditional Roma lifestyle. This can be seen, according to Knezevic, if one follows the role of the Romni, i.e., the Gypsy women, who she believes to have contributed to a great extent to the economic interdependence between the Romni and the city environment, where they worked as psychics, healers, fortune-tellers, dispellers of black magic, cloth resellers and housemaids after World War 2. The second important aspect of the adjustment she sees in the fact that "not an insignificant number of young, pretty girls continue the traditional occupation of the Romni - singers in the kafanas (a type of restaurant, translator's note) in the interior (of the country, note by I.C.R.)" (Knezevic 1982: 288). Konstantinov writes on the same topic about the Romni from Bitola. He generalizes that "they are intelligent women who cast spells and tell one's fortune" (Konstantinov 1982:268).

\section{The natural connectedness of the Roma}

Specifically, Konstantinov, who hailed from the then-Socialist Republic of Macedonia, as early as in the article from 1982 establishes the "natural" connectedness of the Roma based on certain anthropological traits, the collective health circumstances. These spiritual features made up the Roma mentality and a range of other features because they should be classified in a single category, "minority." In his attempt to discuss the Roma anthropological traits, Konstantinov first discusses the need for systematic and comprehensive anthropological measurements which had not been previously done in this community. As a result, he establishes their anthropological traits "based on longer-term visual observations" (Konstantinov 1982: 255-256). Thus, he notices that the anthropological characteristics can be determined based on the shape of the head. Then he generalizes that the dolichocephalic, brachycephalic and mesocephalic heads are the most prevalent and that in most cases, the heads of the Roma are dolichocephalic. This random feature of the Roma he then complements with the most frequent "racial" elements of the Roma, according to which their hair is black and their eyes; their eyebrows are thick, and their facial features are mainly regular.

In his view, both men and women in most cases have pretty faces, a skin tone that varies between very dark to lighter, brighter, and in some cases even has nuances of white; that some men have athletic bodies. The continuity of the Roma community, in Konstantinov's view, can be seen in the continuity of the beauty of the Romni and girls that he believes are among the most beautiful in the Balkans, and, in his view, this is true 
even in the period he is talking about. One of the essential characteristics can be found in the body features of the Romni, whose "bust is more developed, and so they frequently have uncommonly luscious breasts." Little children are cute and pretty, both genders in equal measure. Konstantinov emphasizes their most considerable virtues in terms of their spiritual features, so he says that the Bitola Roma are cheerful and vivacious regardless of whether their life circumstances are excellent or dire. That they are pretty witty and that they frequently laugh wholeheartedly and joyfully. That for them, singing, dancing, and playing instruments are the most significant values in everyday life, and since they are not at work, where they cannot act freely, they start their day with songs and music; they welcome the night in the same way, and sometimes the merriment continues deep in the night until they get exhausted and can't wait to get to sleep. He points out specific characteristics of their disposition; namely, he says that they are restless, spirited, lose their temper quickly, but that, in essence, they are peaceful and rarely get into fights with strangers, but do that more often among themselves. To confirm that, Konstantinov illustrates this trait with an imaginary event, a row incited by using an offensive word, which resulted in a fist-fight. Thus, in his attempts to illustrate their propensity towards fistfighting, he mentions that there had only been two to three brawls in the past two to three years. Konstantinov embellishes the depiction of the brawl with an image of "all adults going out with already prepared special canes. The moment the men clash, everybody hitting everyone else, both guilty and innocent, the women and children also get involved to calm them down. They pierce through the crowd and yank the people who were fighting home. The dangerous ruckus dies down the moment the uniformed police appear at the scene" (Konstantinov 1982:268). This image of emotional disbalance Konstantinov embellishes with the claim that the Roma are frequently melancholic, so "in such moments of general melancholy they soften up, like cuddled toddlers..."

\section{The Roma "otherness" in Macedonian ethnology, as well.}

After the Republic of Macedonia became independent from SFR Yugoslavia in 1991, a process of nationalization of social and humanist disciplines and institutions was initially slow, but then much faster, and it became of utmost importance that the research focuses on Macedonian national culture. Thus, the number of researchers dealing with topics related to the Roma and other ethnic communities started to dwindle. Only the Roma researchers, whose number today has decreased, continued to research the Roma communities. In this sense, in the research institutions, as well, the idea stemming from the Yugoslavian era - examination of the culture of the smaller communities to be carried out by insider researchers, researchers from the communities, who are the most competent to study and write on topics related to the context they come from - continued to be endorsed. In addition, there are no changes to the theoretical and methodological approach the Roma researchers used in their research and in the trends in terms of the research topics they have selected, so they broadly do not diverge from the previous approach, to follow "the traditional Macedonian Roma culture, seen through the prism 
of the various ethnological developments, systematized in its three segments - the material, social and spiritual culture" (Petrovski 2013: 6). According to the author, the Roma culture should be followed based on these three most significant segments, which encapsulate the lifestyle in the Roma community in the Republic of Macedonia. However, as time went by, it became apparent that this traditionalistic categorization in the research approach for the Roma culture, inherited from the science of ethnology from the early 20th century, can not meet the research needs that appeared later when the issue of selecting the most appropriate method for researching the modern sociocultural contexts in the Roma communities came up.

This goes to show that even though in the approach typical of the "70s and '80s in Yugoslavian ethnology, a lot of attention is paid to the cultures of the minorities and the researchers coming from the minorities, after the Balkan states became independent, including the Republic of Macedonia, this strategy of strengthening the efforts for educating young Roma ethnologists is being abandoned as it is perceived to be insignificant. As Macedonian ethnology does not know how to treat it, it puts it in a position of a marginalized culture. On the other hand, the Roma researchers, educated in the era of SFR Yugoslavia, who are now advanced in age, continue to write about the Roma communities in the same manner; in fact, the research quality has even begun to diminish, since in the period after 2010, they have started to regurgitate the papers without positioning the topic in a modern sociocultural context.

\section{The portrayal of the "otherness" of the Roma in Macedonian ethnology and anthropology}

Since the Republic of Macedonia became independent from SFR Yugoslavia in 1991, only a handful of Roma ethnologists usually write papers without any effort to leave the traditional comfort zone, where research is focused on the national tradition. Thus, research related to the modern Roma contexts in this period is very scarce or virtually non-existent. It becomes interesting after 2010 for researchers who are not Roma and for researchers out of the Republic of Macedonia.

Immediately after 2010, the research approach of the Roma ethnologists is headed in the same direction. In most of the papers, the overall concept is viewing Roma tradition through the example of the calendar customs. However, unlike them, some other non-Roma researchers interested in the folk tradition, include processes of transformation of the national tradition in modern culture, again viewed through the transformation of the customs for the holidays Vasilica and Gjurgjovden.

However, in the papers of the Roma researchers educated in the time of SFR Yugoslavia, one can notice a regurgitation on the Roma tradition in the "80s in the ethnological publications after 2010. The papers are regurgitated to such an extent that there is an example in the Macedonian ethnological literature of an article published in a scientific journal in the " 80 s or ' 90 s, with some minor adjustments and without any new ethnographic data or ethnological analysis of ethnographic material that would 
match the modern context, being reissued in 2013 in a different scientific journal with a new title. Thus, in this paper, as in the papers in the '80s, one of the key aspects for the Roma continues to be the shape of the head which is noticed after more extended observations, as a piece of essential scientific evidence that the Roma are physiologically close to representatives of certain peoples in North India.

Such a scientific and research-centered approach in Macedonian ethnology and anthropology, regardless of whether we are talking about Roma researchers or not, contributes to the further support of stereotypes for the Yugoslavian Roma that were created of the '70s and '80s in Yugoslavian ethnology, in which the concept of Roma folk tradition is presented as a static, inert category, which supports the ideas and the images of the Roma from the '70s and ' 80 s, with the excuse that they are scientifically justified without any consultation of the data from the modern Roma sociocultural context.

\section{CONCLUSION}

This paper has used interpretations of ethnographic texts published in proceedings dedicated to the Roma in the period of the '70s, ' $80 \mathrm{~s}$, and '90s, as well as research monographs and papers published since the independence of the Republic of Macedonia, to establish the way the image for the Roma was built in the Yugoslavian, and then also in the Macedonian literature after it adopted the same model. Thus, on the one hand, an Orientalized image for the male and female Roma is being constructed as a Yugoslavian "otherness," and on the other hand, the Roma community is being seen through the prism of an inert category, i.e., Roma tradition.

Such a scientific and research-centered approach in Macedonian ethnology and anthropology, regardless of whether we are talking about Roma researchers or not, contributes to the further support of stereotypes for the Yugoslavian Roma that were created of the '70s and ' 80 s in Yugoslavian ethnology, in which the concept of Roma folk tradition is presented as the only area of interest that can prove that this community is a static, inert category. That supports the ideas and images of the Roma in the '70s and ' 80 s and continues to be supported under the excuse that they are scientifically justified without consultation of any data from the modern Roma sociocultural context. 


\section{References}

Бајрактаревић, Милун. 1982. „Теоријско-методолошка оријентација југословенске етнологије“, Ейнолоки ӥреїлеg 17: 155-162.

Балић, Саита. 1992. Поздравна реч Саита Балића, Претседника међународне организације Рома, во: Развийак Рома у Југославији, проблеми и тенденције, Научни скупови, Књига LXVIII, Књига 1. 3-4. Београд: САНУ Оделење друштвених наука, Комисија за проучавање живота и обичаја Рома.

Каназира, Душан. 1993. Поздравна реч академика Душана Каназира, претседника САНУ, во: Друшишвене ирромене и йоложај Рома, Научни скупови, Књига LXX, Књига 2. 3-4. Београд: САНУ Оделење друштвених наука, Комисија за проучавање живота и обичаја Рома.

Кнежевић, Сребрица. 1982. „Жене Рома и њихов смисао за адаптацију у складу са

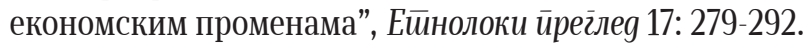

Константинов, Душан. 1982. „Етнички одлики на битолските Роми“, Ейнолоки ӥрег̈леg 17: $247-278$.

Мацура, Милош. 1992. Уводна реч академика Милоша Мацуре, во: Развийак Рома y Jугославији, проблеми и тенденције, Научни скупови, Књига LXVIII, Књига 1. 1-2. Београд: САНУ Оделење друштвених наука, Комисија за проучавање живота и обичаја Рома.

Петровић, Ђурђица. 1992.„Научна истраживања Рома у Југославији“, во: Развиш̄ак Рома у Југославији, проблеми и тенденције, Научни скупови, Књига LXVIII, Књига 1. 61-83. Београд: САНУ Оделење друштвених наука, Комисија за проучавање живота и обичаја Рома.

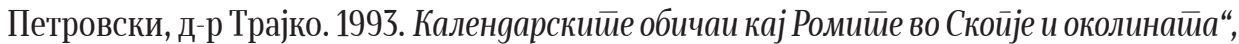
Скопје: Феникс.

Петровски, д-р Трајко. 2013. „Етнокултурните карактеристики на Ромите во Крива Паланка“, во: Славишки зборник 2: 239-251. Крива Паланка: Градски музеј. 


\section{EthnoAnthropoZoom}

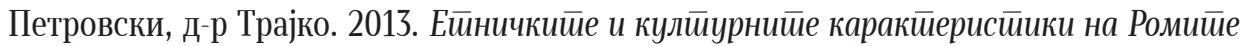
во Макеgонија, Посебни изданија, Книга 82, Скопје: Институт за фолклор „Марко Цепенков“.

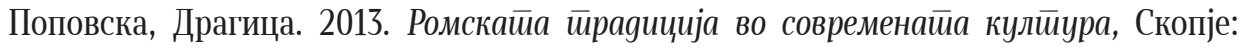
ИНИ.

Старк, Еја. 2016. „Политиката на фолклорот, начинот на неговото собирање: фолклорот поврзан со ромското население во Финска во раниот 20 век“, ЕйноАнйройоЗум 15: 150-174.

Тодорова, Марија. 2001. Замислувајќи го Балканой. Скопје: Магор.

Rot, Klaus. 2000. Slike u glavama. Ogledi o narodnoj kulturi u jugoistočnoj Evropi, 113. Ivan Čolović(ur.). Beograd: Biblioteka XX vek. 
EthnoAnthropoZoom 